\title{
Europe and Central Asia in China's Belt and Road' Initiative: A Multidimensional Analysis of Trade Intensiveness
}

\author{
Vivien Kitty Molnár ${ }^{1}$, Dechun Huang ${ }^{1}$, Md. Ekram Hossain ${ }^{1}$ \\ ${ }^{1}$ Institute of Industrial Economics, School of Business, Hohai University, Nanjing, China \\ Correspondence: Vivien Kitty Molnár, Institute of Industrial Economics, School of Business, Hohai University, Nanjing, \\ China.
}

Received: October 28, 2019

Accepted: December 10, $2019 \quad$ Available online: December 24, 2019

doi:10.11114/aef.v7i1.4586

URL: https://doi.org/10.11114/aef.v7i1.4586

\begin{abstract}
From the middle of 90's, the bilateral trade between China and Europe and Central Asia (EU-CA) has become more important in the world trade. In 2013, the Chinese government introduced its new economic policy, the Belt and Road Initiative (BRI), which opened a new are of the world trade's history. This paper is attempt to measure strength and nature of bilateral trading relationship between China and EU-CA. Furthermore, we are looking for the answer how the BRI is affecting on the studied countries' economies. Many statistical indices can be used to measure international trade relations. This paper has used one such index such as trade intensity. Trade intensity indices have been calculated for the period from 1997 to 2017. Described intensity indices of bilateral trade relations, both countries will help determine how intensively countries that trade with each other. Thus, this study found that intensity between two countries is high and the BRI did not increase the trade intensiveness between China and EU-CA as we were expecting.
\end{abstract}

Keywords: international trade, belt and road initiative, China, Europe, Central Asia, trade intensity

\section{Introduction}

While in the 19th century Europe was the economic center of the world, in the 20th century it moved to the US. In the 20th century, there were a number of historically and economically significant turning points that had a major impact on world trade, changing the role of the countries in the world market. As a result of globalization, the role of countries has changed radically. Within sixty years two countries have risen, Japan and China and in the 21st century China is one of the most powerful and dominating country in the world. As we can see, the economic center of the world is moving spectacularly eastward.

Before 1979, China was comparatively isolated from the global economy, that's why the economy was very poor and inefficient. Subsequently, China opened its gates to free trade and capital flows, the country enjoyed a number of favorable backlogs. A new era has begun in Chinese history, which included all kinds of changes. Today the Chinese economy has been among the world's fastest-growing economies, has become one of the world's largest and most powerful economy.

The late 1980s and early '90s was a significant period in Eastern, Central European and Central Asian areas because after the dissolution of the Soviet Union dozen countries became independent. After gaining independence, they had to face a lot of economic problems. The political stability of the new democracies in former Soviet republics and elsewhere in Central Asia and Eastern Europe was being threatened by widespread poverty, rising unemployment, and declining growth rates (Martin Myant 2016).Compared to their economies, with the Western European countries', they were less developed, they had to encourage their economic to join the world market. From the late ' 90 s the Central-Eastern European and Asian countries cooperation with China became more successful and it helped the post-communist countries to raise a competitive market.

At the end of the 20th century the technological development and globalization have opened a new era in history, world trade has begun to develop to a great extent and international trade has become a new scene, as inter-country trade policy has become more and more open.

During the last few decades China's trade relations between Europe and Central Asia have strengthened which is a great initiative on both sides. The relationship between China and these 2 regions has become more intensive after 2013, 
when Xi Jinping introduced the new Chinese trade policy, the Belt and Road Initiative. In this program they would like to re-build the great historical Silk Road. BRI has been called a Chinese Marshall Plan, which is nowadays the biggest economic and diplomatic program all over the world, crossed Asia, Europe, Middle East, Latin America and Africa (Huang 2016). Nowadays more than 150 countries are part of this great initiation, which shows how important this program in these countries' lives. This program helps China to strengthen its trade relations between countries of the world and it also helps the trade partners to make a greater progress in their economies. From 2011 European and Central Asian region have playing a bigger role in this initiative, which means the export and import is more intensive than before.

The trade performance sits at the very core of the success experienced by the very globalized economies of Europe, Central Asia and China (Shang 2016). Because of the BRI, our hypothesis is that trade intensity tent to increase between these regions.

The main objective of our paper is to understand deeply the bilateral trade intensity between Europe, Central Asia and China. Furthermore, we are looking for the answer, how BRI has affected on both side. In the next Section, we shall offer an intuitive explanation of previous researches on the Belt Road Initiative and trade intensiveness, then Section 3 describes the new dataset that we have structured. Section 4 present the overall results for our set countries, firstly results of trade intensiveness then we introduce the trade intensity index result, where we can see how strong countries export power. The discussion in Section 5 evaluate the implications of our results for a wider understanding.

\section{Literature Review: An Overview of the BRI and Trade}

Economic growth take place when "liberalization of trade through policy induced measures by reducing and then eliminating tariff and non-tariff barriers promotes efficiency of allocation of resources to productive uses, exploitation of scale economies, encourages competition, increases factor productivity and increases trade flows, thereby, promoting economic growth" (Barro, 1995). This methodology on a theoretical plane is working well, in the reality is different. "In spite of instituting various measures of trade liberalization in many countries, still there remain some country-specific barriers, which impede the growth of world trade" (Kalirajan, 1999).

The new Chinese economic policy, the Belt and Road Initiative involves more than 150 countries, international organizations in Europe, Asia, Middle East, Latin America and Africa. That's why it is not astonishing that this program has attracted huge attention worldwide. A lot of studies speak of this new global phenomenon from different perspectives, including motivation, routes, barriers. (Szczudlik-Tatar 2013; Brugier 2014; Arase 2015; Kaczmarski 2015; Lo 2015; Du 2016; Huang 2016).

It was thought that China with this new Chinese economic policy, would like to establish and make its economic more powerful, by narrowing the development gap between China's eastern and western regions. Brugier (2014), Kaczmarski (2015), and Arase (2015) also described the concept of the New Silk Road. Lo (2015) considered the BRI a proverbial stone with which to kill three birds at once: the implementation of the BRI would boost renminbi internationalization, help export China's excess capacity, and secure China's foreign trade relationships. Li et al. (2015) emphasized that a new and sustainable Silk Road should be established by advancing scientific research and reinforcing international collaboration.

The experts of the first level draw attention to the geopolitical nature of the BRI, viewing it as a key measure in China's transformation into the world's factory, allowing it to bring goods to international markets, and putting it on the same level as the USA and European countries (Syroezhkin 2016). The BRI aims to achieve military, political, and cultural goals by increasing China's influence on a regional and worldwide level (Caa-network.org 2018).

Bilateral trade relations and their intensity have appeared as one of the fundamental topic in international economics. The gravity model (in basic or modified form) has become an important analytical tool for examine a wide range of determinants of bilateral trade processes. Therefore, trade intensity indexes allowed assessing whether the value of trade between two countries is greater or smaller than would be expected on the basis of their importance in world trade. In addition, Frankel (1997) introduced a trade intensity indicator for 'regional trading blocks' to assess whether the region exports more (in percentage) to a given destination than the world average. Empirical evidence based on various trade gravity models and various trade intensity indices belongs to a wide variety of bilateral trade relations studies (Folfas 2011).

The intensity of trade index was pioneered by Brown (Agnew and Crobridge 2002) and was later developed and popularized by Kojima (Kojima 1964). Kojima's intensity of trade index concentrates on variations in bilateral trade levels that result from differential resistances (Bano 2014). Trade with a country can be more intense than with the rest of the world, as resistance is lower. Trade Intensity help to measure these trade relationships without distortion due to comparative size of trading partners (Bano 2014). When examining the strength of trade relations, it is often desirable to consider the importance of the country's trading partners in world trade. (Bhattacharyay and Mukhopadhyay 2015) 
(Chase-Dunn, Kawano, \& Brewer, 2000). One group of indices that do this is the trade intensity index (TII) (WITS 2019). The intensity of bilateral trade between two countries can be measured from either an export or import perspective. The trade intensity statistic is the ratio of two export shares (Raj, Wing et al. 2014). The numerator is the share of the destination of interest in the exports of the region under study. The denominator is the share of the destination of interest in the exports of the world as a whole (ARTNET 2013).

\section{Data and Methodology}

The index determines whether bilateral trade between countries $i$ and $j$ is greater or lesser than might be expected given the importance of the trading partner's share in total world trade. The trade intensity indices discussed by Bano (2010) allow to measure the strength of trade relations without distortion caused by the comparative size of trading partners. A value greater than one indicates that the relationship between the home country and the trading partner is greater than is expected given the trading partner's share of world trade, while a value of less than one indicates that the strength of the trading relationship is less than is expected.

\subsection{Export Intensity Model}

$$
\begin{gathered}
X I I=\frac{X_{i j} / X_{i w}}{M_{j w} /\left(M_{w}-M_{i w}\right)} \\
X I I=X_{i j} / X_{i w} \div\left\{M_{j w} /\left(M_{w}-M_{i w}\right)\right\}
\end{gathered}
$$

$\mathrm{XII}_{\mathrm{i}}$ represents the export intensity index for country $\mathrm{i}$;

$X_{\mathrm{ij}}$ represents the value of country i's exports to country $\mathrm{j}$;

$X_{\text {iw }}$ represents the value of country i's total exports to the world;

$\mathrm{M}_{\mathrm{jw}}$ represents the total value of imports from the world into country $\mathrm{j}$

$\mathrm{M}_{\mathrm{w}}$ represents the value of total world imports;

$\mathrm{M}_{\mathrm{iw}}$ represents the total value of imports from the world into country $\mathrm{i}$;

The index shows whether bilateral exports between countries $i$ and $j$ would be higher or lower than expected given the importance of the trading partner's share in global trade. As Bano (2008) and Bano and Tabbada (2012) discussed the trade intensity indicators, they provide an opportunity to measure the strength of trade relations without any distortion caused by the comparative size of the trading partners.

The value greater than one indicates that the relationship between the home and the trading country is more than we can expect, when we take into account the trading partner's share in world trade, while the value is lower than one, it means that the strength of trading relationship is less than is expected (Bano and Tabbada 2012).

Limitations: As with trade shares, high or low intensity indices and changes over time may reflect numerous factors other than trade policy (WITS 2013, Database 2018).

3.2 Import Intensity Model

$$
\begin{gathered}
M I I=\frac{M_{w} / M_{i w}}{X_{j w} /(X w-X i w)} \\
M I I=M_{i j} / M_{i w} \div\left\{X_{j w} /(X w-X i w)\right\}
\end{gathered}
$$

Where: $\mathrm{MII}_{\mathrm{i}}$ represents the import intensity index for country $\mathrm{i}$;

$\mathrm{M}_{\mathrm{ij}}$ represents the value of country i's imports from country $\mathrm{j}$;

$M_{i w}$ represents the total value of imports from the world into country $i$;

$\mathrm{X}_{\mathrm{jw}}$ represents the total value of country j's exports to the world;

$X_{w}$ represents the total value of world exports;

$X_{\text {iw }}$ represents the value of country i's total exports to the world;

If the value greater than one determines, means that the relationship between the home and the trading country is better than is expected given the trading partner's share of world trade. If the result is less than one, means that the strength of the relationship is worse than is expected. 
Limitations: As with trade shares, high or low intensity indices and changes over time may reflect numerous factors other than trade policy (WITS 2019).

\subsection{Trade Intensity Model}

The Trade Intensity Model is used in this research to analyze the export import and trade intensity between China and the selected competitors from to period. In order to examine whether the bilateral trading relationship between China and the concern market is strengthening or weakening, both export-intensity index and import-intensity index have been estimated. Here, China is reported as the home country $i$ and trading partner (Europe and Central Asia) as country j. For trade flows from country i to country $\mathrm{j}$, these indices are measured as follows:

$$
\begin{aligned}
& T I I=\frac{X_{i j} / X_{i t}}{X_{j w} / X_{w t}} \\
& T I I=\left(X_{i j} / X_{i t}\right) \div\left(X_{j w} / X_{w t}\right)
\end{aligned}
$$

$\mathrm{TII}_{\mathrm{i}}$ represents the Trade intensity index for country I

$X_{i j}$ represents the value of country i's exports to country $j$;

$\mathrm{X}_{\mathrm{it}}$ represents the value of country i's total exports to the world;

$X_{j w}$ represents the total value of country $j$ 's exports to the world and

$\mathrm{X}_{\mathrm{wt}}$ represents the total value of world exports.

$$
\begin{aligned}
& w x(i, j, T)=\ln \left(\frac{1}{|T|} \sum_{t \in T} \frac{x_{i j t}}{X_{i t}+X_{j t}}\right) \\
& w m(i, j, T)=\ln \left(\frac{1}{|T|} \sum_{t \in T} \frac{m_{i j t}}{M_{i t}+M_{j t}}\right) \\
& w t(i, j, T)=\ln \left(\frac{1}{|T|} \sum_{t \in T} \frac{x_{i j t}+m_{i j t}}{\left(X_{i t}+X_{j t}\right)+\left(M_{i t}+M_{j t}\right)}\right)
\end{aligned}
$$

Following the method of Frankel and Rose (1998), three different proxies for bilateral trade intensity are used: wx, wm, and wt. The first proxy uses export data only, the second uses import data only, and the third uses both:

where xijt denotes total nominal exports from country $i$ to country $j$ during year $t$, mijt denotes the total nominal imports from country $\mathrm{j}$ to country i during year $\mathrm{t} ; \mathrm{X}$ and $\mathrm{M}$ denote total global exports and imports for the corresponding country, and $\mathrm{T}$ is period, which is a set of ten years, thus $\mathrm{T}=$ Period 1 or Period 2. There are some limitations as well. As with trade shares, high or low intensity indices and changes over time may reflect numerous factors other than trade policy.

Since the mid-nineties, after the end of the Soviet Union, a stronger trade relationship has emerged, but as a result of the global economic crisis, trade relations between countries had weakened. From 2013 onwards has given new impetus to China's trade relations with Europe and Central Asia. That's why we have counted for a 20-year period, between 1997 and 2017 (Figure 1).

The data in our analysis are furnished by United Nations Commodity Trade database (UN COMTRADE Database, 2018) and World Trade Organization (WTO, 2018). During our calculations, we have used data of export and import between China and the European region, data of the World's export and import and data of export and import between selected countries and the World. To analyze the indices Microsoft Excel software was used.

\section{Result and Discussion}

\subsection{Trade Intensiveness}

The Figure 1 gives the export and import intensity indices of China to Europe and Central Asia. From the analyzed results the following reconciliations are come out. The export intensity value of China to Europe and Central Asia is around 0.4. During the 20 years studied, the index has not changed significantly. This value is not negligible, because it is not close to zero, which means that the export level from China to Europe and Central Asia is higher than that China's in the world market share. 


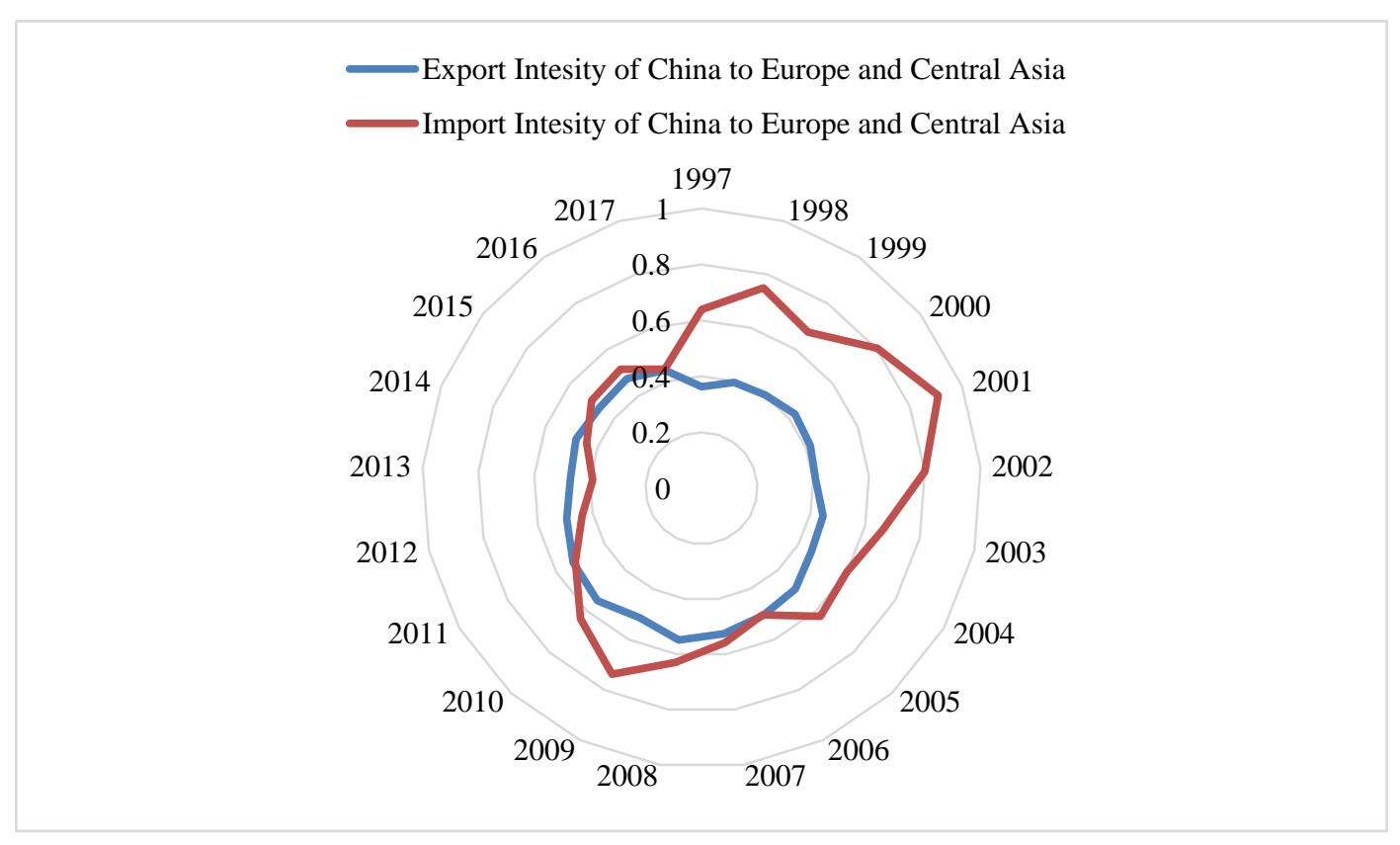

Figure 1. Export and Import Intensity Index of China to Europe and Central Asia between 1997-2017

Description: The intensitivity of the trade was examined, whereby the following results were obtained by the above method.

The import intensity index is more noticeable, compare to the export intensity index. We can see that the import intensity level is waving. During this 20 years, there were 3 major breakpoints, data shows downward trends after growths. Firstly, the growth stopped in 1998 due to the Russian economic crisis, which had an impact on world trade. After the Russian crisis, the value was growing rapidly since 2001, when the import intensity index almost reached one (0.91). From 2001, the value was steadily decreasing. Two years before the global economic crisis, the index was in a rising period again, but after 2008 , because of the global economic issue, the value dropped dramatically. In this period the level of trade had fallen worldwide.

After the crisis, trade relations have accelerated between China, Europe and Central Asia, where we would expect an upward trend, but the value continued to decline. This phenomenon may be credited to the fact that after 2003, new economic and trade agreements were made around the world, through which the world economy has become more open to trade and the countries investigated seizing new opportunities, and they can trade with other countries on more favourable terms. This is one of the reason why the level of World's export and import has been increasing more intensively than the level of the European and Central Asian export and import (Figure 4).

It is revealed from Figure 1 that China's import intensity with EU-CA is above 0.5 for most of the years. This means China's imports are intense with EU-CA countries compared with its trading pattern with rest of the world.

During 20-year studies, most of the years, the Import Intensity Index is higher than Export Intensity Index as it imports more from EU-CA compared to its exports. Just at the end of 2017 were in the same level (0.44) the Export and Import Intensity Indexes. We were expecting other results, because we thought that, because of the BRI, the relationship between China and EU-CA would be stronger and trade would be more intensive. The calculations are even explained by the fact that world trade has increased dramatically and in the recent years China has reinforced its trade routes.

The Figure 2 gives the Export and Import Intensity Indices of Europe and Central Asia to China. The export intensity value of Europe and Central Asia to China is stagnating at around 0.2, which means that the export level from Europe and Central Asia to China is highly lower than that region's in the world market share, but not negligible since the value is not close to zero. After 2013, when China introduced its new economic policy, the Belt and Road Initiative, the value of index started to increase slightly. According to the calculations, rate of EU-CA Export Intensity Index is the half of the Chinese value. This means that, China exports much more intensively then EU-CA countries. 


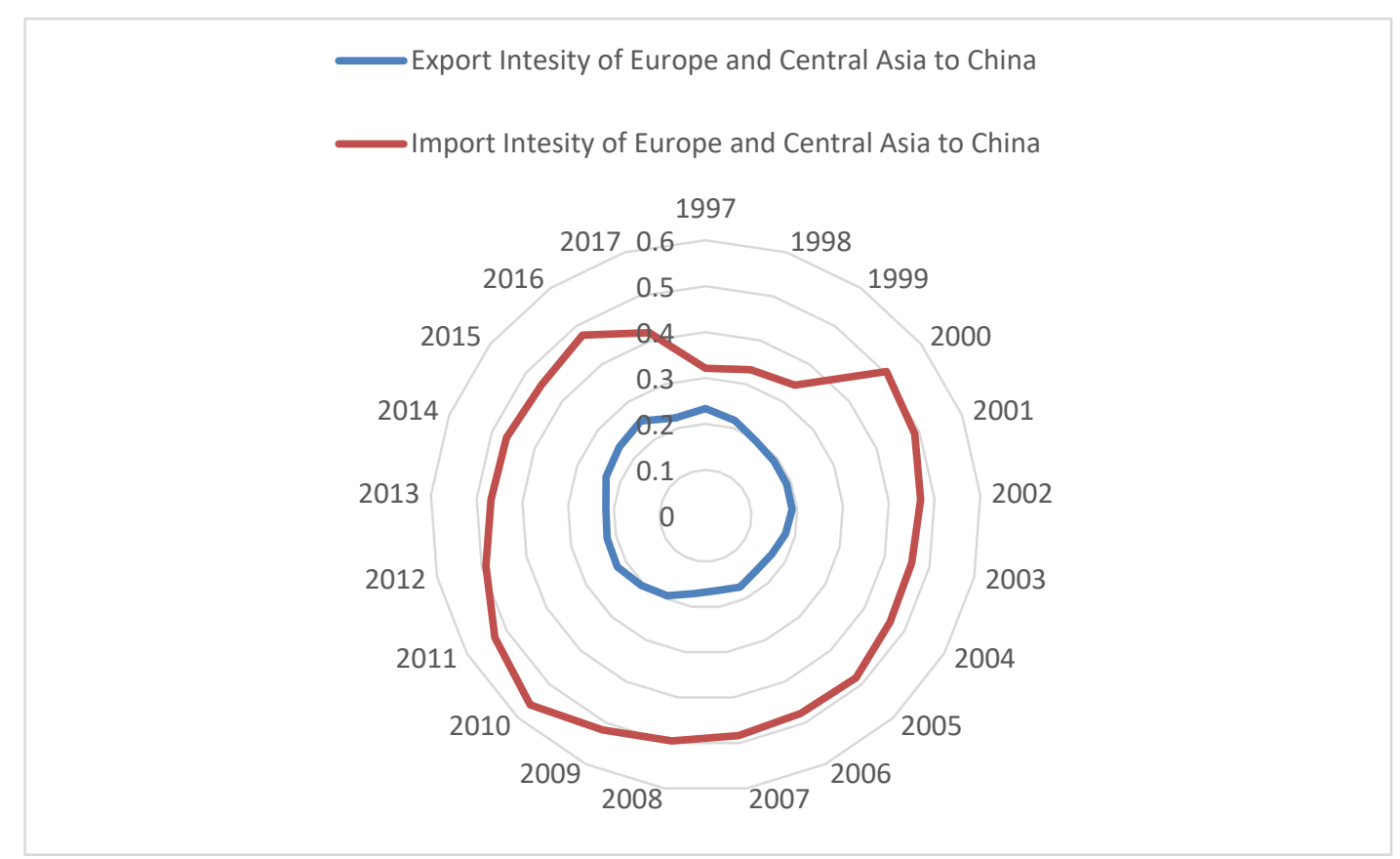

Figure 2. Export and Import Intensity of Europe and Central Asia between to China 1997-2017

Description: The intensitivity of the trade was examined, whereby the following results were obtained by the above method.

In term of import intensity of Europe and Central Asia from China during 1997 to 2017 is less than one, but not near to zero (Figure 2), which means interprets that the import level from China to Europe and Central Asia is higher than that of European and Central Asian share of the import from the world.

Between 1999 and 2000, the value increased rapidly and then moved steadily to a value of 0.5 , and in 2010 the value increased again. The effects of the global economic crisis were only felt after two years, in 2010, when the value of the indicator slowed down. The Belt and Road Initiative did not bring greater prosperity for import, the value of the index has not changed dramatically, furthermore in 2017, the rate of the Import Intensity Index significantly decreased.

\subsection{Total Intensity Index}

Figure 3 shows the Total Trade Intensity Index of China and EU-CA. The Chinese value shows that the intensiveness is lower than one (1), but it is far from zero (0), which means that the trade is intensive. During this 20-year period, the Chinese value was growing rapidly between 2002-2008, but because of the financial crisis, high rate of growth stalled and then from 2009 the value continues to decrease slowly.

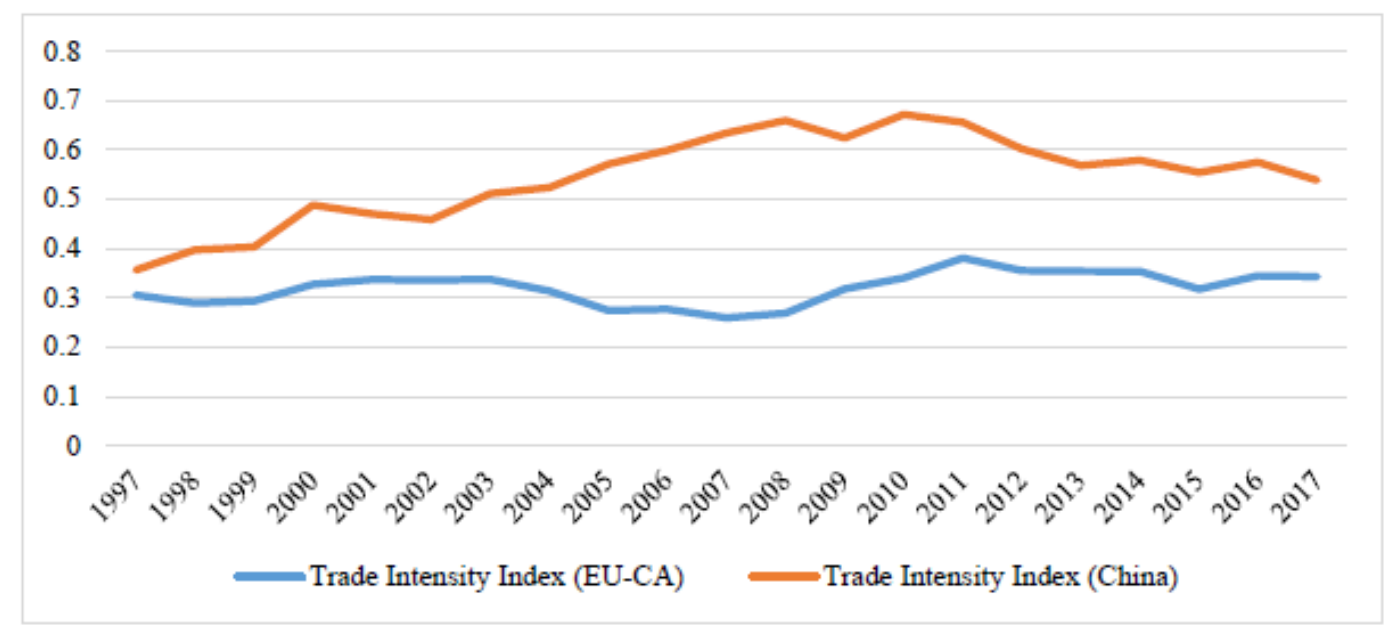

Figure 3. Total Trade Intensity 
Description: The intensitivity of the trade was examined, whereby the following results were obtained by the above method.

The index of EU-CA shows similarities, but also deviations compared with the Chinese value. The trade is intensive, because the value is far from zero (0), but not as intensive as the Chinese rate. In both case, the value decreased in 1999, because of the Russian economic crisis, then both of the values continued to increase. The biggest deviation starts from 2003, when the two values were moving in the opposite direction; the Chinese value was constantly devenloping, while the EU-CA's value had a downward trend. Between 2004-2009 the difference between the two values was greater than 0.4 (Figure 3).

This phenomenon is influenced by several factors. First of all in 2004 there was the largest single expansion of the European Union, when 10 countries joined to the EU. After it, the western European countries were concentrated on to get great opportunities from the new members, and the European trade was concentrated on the nem members' countries. Furthermore In the early 2000s, as a result of globalization, foreign trade relations have become more and more diverse, thus ensuring more effective world trade. That's why countries have started to trade with other countries, those who have not had the opportunity to trade before. Because of this new these days new trade partners might provide better terms for trade. Because of this, the level of the World export and import level was increasing rapidly (Figure 4).

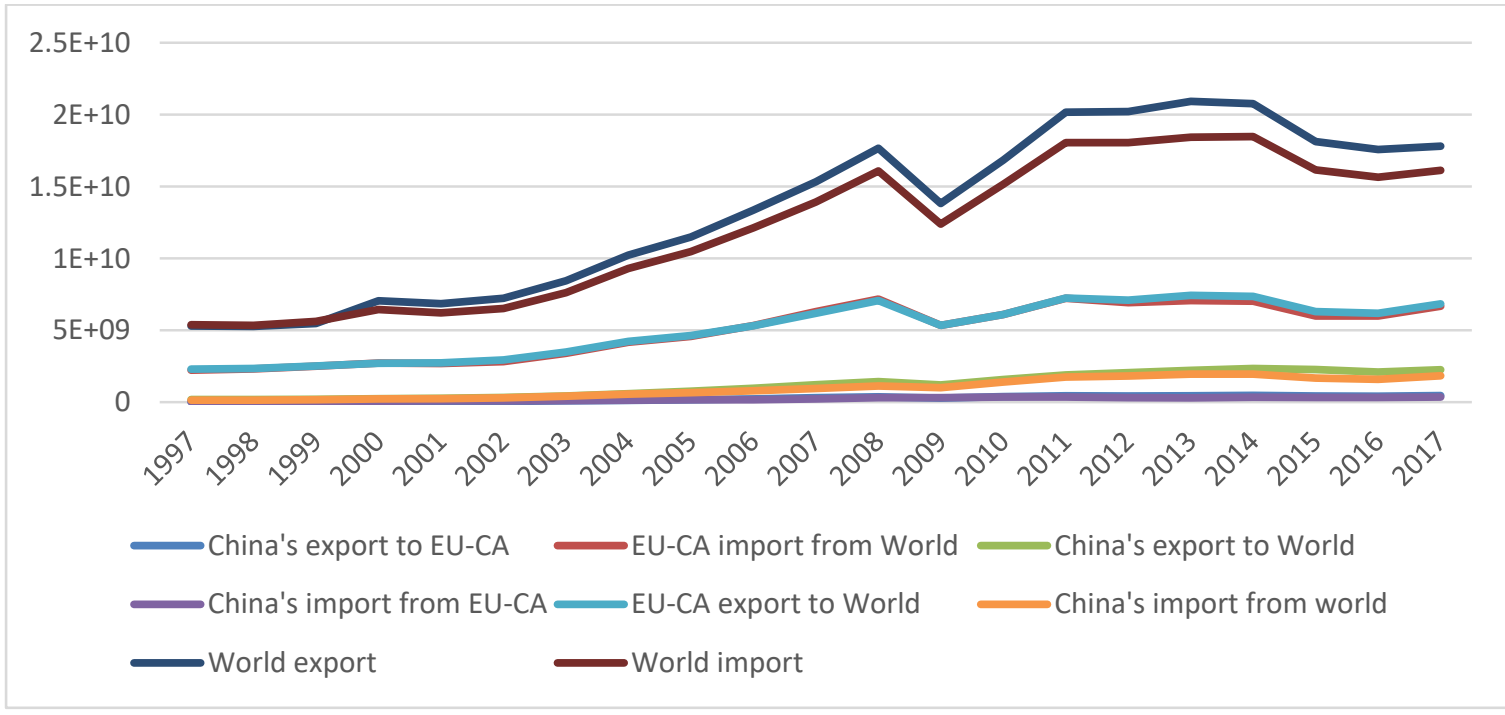

Figure 4. Bilateral trade between China, Europa and Central Asia (EU-CA) and state of world trade between 1997-2017 (US Dollar Thousand)

Description: For the purpoe of examining the intenity, different data were needed, which took into account not only the trade between China and EU-CA, but also we had to calculate with data of world trade.

These factors may cause that value of EU-CA was decreasing between 2003-2008. After the financial crisis, the rate was incrasing slightly, then from 2013, another decline is seen.

In both case, after 2013, when the Chinese government represented its new economic policy, the intensity index was decreasing slowly (Figure 3), did not turn the trade into a positive direction Figure 1 shows that the volume of the world trade was growing much more greater, than the volume of Chinese and European, Central Asian export and import, that's why the trade intensity index did not increase as much as we expected.

\section{Conclusion}

This paper explores the trade between China, Europe and Central Asia, including trade intensiveness. We were looking for the answers how the intensity of demand between the two regions has evolved, furthermore how the BRI affected on the studied countries. Our hypothesis was that the trade intensity tent to increase between these regions because of the Belt and Road Initiative. The results show that from both sides the Export and Import Intensity Index is less than one (1), but far from zero (0), which means the studies countries' trade is intensive. 
Our expectation was that, because of the BRI, the trade intensiveness would be higher than before the new Chinese economic policy, but the results shows a different view. The trade between China and EU-CA was rapidly growing after 2003, but the world trade has increased to the same extent or sometimes to a greater extent

Furthermore in 2004 the European Union made the largest expansion in its history, that's why the European countries were concentration on stabilizing their position in the new members' market. These issues caused that the trade intensiveness did not grown as much as we expected.

During conducting this research, the bilateral trade data could be accessed only up to 2018. If the data of 2018 could be accessed, more recent scenario could be explored. This research is carried based on the quantities methods. More effective policy and trade related barriers, opportunities and recommendations could be come out through qualitative research with survey.

\section{References}

Agnew, J., \& S. Crobridge (2002). Mastering space: hegemony, territory and international political economy, Routledge. https://doi.org/10.4324/9780203422380

Arase, D. (2015). China's Two Silk Roads Initiative: What It Means for Southeast Asia. Southeast Asian Affairs, 2015(1), 25-45. https://doi.org/10.1355/9789814620598-005

ARTNET. (2013). Trade Intensity. Retrieved from https://artnet.unescap.org/APTIAD/trade\%20intensity.pdf

Bano, S. (2010). ASEAN-New Zealand Trade Relations and Trade Potential.

Bano, S. (2014). An Empirical Examination of Trade Relations between New Zealand and China in the Context of a Free Trade Agreement.

Bano, S., \& J. Tabbada (2012). Economic relations between New Zealand and the Philippines: An empirical analysis. 53rd New Zealand Association of Economists Annual Conference, Palmerston North.

Barro, R., \& Sala-I-Martin, X. (1995). Economic Growth. New York: McGraw-Hill Elizondom

Bhattacharyay, B. N., \& K. Mukhopadhyay (2015). A comprehensive economic partnership between India and Japan: Impact, prospects and challenges. Journal of Asian Economics, 39, 94-107. https://doi.org/10.1016/j.asieco.2015.06.006

Brugier, C. (2014). China'sWay: TheNewSilk Road. European Union Institute for Security Studies, 14, 1-4.

Caa-network.org. (2018). Initsiativa "Poyas I Put I vliyanie v Tsentralnoi Azii”" [China's "Belt and Road" initiative and its influence in Central Asia]. Retrieved February 15, 2018, from http://caanetwork.org/archives/12138

Database, W. $\quad$ W. $\quad$ I. $\quad$ T. $\quad$ S. (2018). "WITS." Retrieved December, 2018, from https://wits.worldbank.org/CountryProfile/en/Country/NAC/Year/2016/TradeFlow/Import/Partner/all/Product/50-6 3_TextCloth

Folfas, P. (2011). The Intensity of Bilateral Relations in Intra-EU Trade and Direct Investment: Analysis of Variance and Correlation. European Trade Study Group (ETSG): Bern, Switzerland.

Huang, Y. (2016). Understanding China's Belt \& Road Initiative:Motivation, framework and assessment. China Economic Review, 40, 314-321. https://doi.org/10.1016/j.chieco.2016.07.007

Kaczmarski, M. (2015). The New Silk Road: A Versatile Instrument in China's Policy'. OSW Center of Eastern Studies Commentary, 161, 1-9

Kalirajan, K. (1999). Stochastic Varying Coefficients Gravity Model: An Application in Trade Analysis. Journal of Applied Statistics, 26, 185-194. https://doi.org/10.1080/02664769922520

Kojima, K. (1964). The pattern of international trade among advanced countries. Hitotsubashi Journal of Economics 5(1), 16-36.

Lo, C. (2015). China's Silk Road Strategy. The International Economy, 29(4), 54-71.

Martin Myant, J. D. (2016). Transition economies-political economy in Russian, Eastern Europe and Central Asia.

Raj, P. S., et al. (2014). A brief analysis of India-Japan bilateral trade: A trade intensity approach. International Journal of Economics, Commerce and Management, 2(2).

Shang, Y. (2016). The Changing Patterns of China-CEE Trade. Europe-Asia Studies, 68(9), 1486-1505. https://doi.org/10.1080/09668136.2016.1244259

Syroezhkin, K. (2016). Geopoliticheskie proekty v Tsentralnoi Azii I rol Kazakhstana [Geopolitical projects in Central Asia and the role of Kazakhstan]. Retrieved February 10, 2018, from 
http://cabar.asia/ru/konstantin-syroezhkin-geopoliticheskie-proekty-v-tsentralnoj-azii-i-rolkazahstana

Szczudlik-Tatar, J. (2013). China's New Silk Road Diplomacy. PISM Policy Paper, 34, 1-8.

Wilson, J. S., Mann, C. L., \& Otsuki, T. (2004). The Potential Benefit of Trade Facilitation: A Global Perspective. World Bank Policy Research Working Paper, 3224, February

WITS. (2013). Trade Outcomes Indicators. T. W. Bank. Washington DC.

WITS. (2019). Trade Outcomes Indicators. Retrieved from http://wits.worldbank.org/WITS/docs/TradeOutcomes-UserManual.pdf

\section{Copyrights}

Copyright for this article is retained by the author(s), with first publication rights granted to the journal.

This is an open-access article distributed under the terms and conditions of the Creative Commons Attribution license which permits unrestricted use, distribution, and reproduction in any medium, provided the original work is properly cited. 